\title{
Evolving a Planning Strategy for Managing Urban Sprawl in Nigeria
}

\author{
Julius Olujimi \\ Department of Urban and Regional Planning, School of Environmental Technology, Federal \\ University of Technology, Akure, Ondo State, Nigeria \\ E-mail: olujimi54@yahoo.com
}

KEYWORDS Urbanisation. Development Control. People-Oriented Strategy. Local Planning Authority. State Urban and Regional Planning Board

\begin{abstract}
The increasing urban sprawl in most cities in developing countries continues to attract attention of national and international agencies but the efforts had not achieved much result at checking the sprawl. There is the need therefore to re-evaluate these efforts and make necessary suggestions that would reverse the trend. This study investigates the problems of urban sprawl in Nigeria. It utilizes published and unpublished materials as well as sundry informal investigations (i.e. observations) of the stakeholders in the development and management of urban sprawl in Nigerian cities. The paper presents the urbanization trends in Nigeria and discusses the characteristic features of urban sprawl in its cities as well as identifies the various factors responsible for the urban sprawl. It evaluates strategies adopted so far at curtailing the sprawl. A major limitation of the various strategies adopted is the inadequate involvement of the people (developers) at checking the sprawl. The paper therefore suggests a people-oriented strategy in checking urban sprawl in Nigerian cities; which is expected to be facilitated by the government planning officials.
\end{abstract}

\section{INTRODUCTION}

The world is increasingly becoming urbanized and the rate at which city populations grow and countries urbanise is indicative of the pace of social and economic change (Donk 2006). In 1976, one-third of the world population lived in cities and 30 years later (2006), this rose to one-half of the entire humankind (Tibajuka 2006); and by the target year for the Millennium Development Goals (MDGs); cities in the world are estimated to grow to two-third or 6 billion people by 2050 (UNHabitat 2006).

With nearly all global demographic growth that is mostly concentrated in developing countries, urban sprawl is becoming a major feature of the developing countries. Useful as they may be as demographic absorbers, metropolitan regions by their sheer size, create complex and multifaceted problems on scales never experienced before. The effects of this population dynamics in African cities in particular produced miseries that are often difficult to comprehend (Olurin 2003). Most of the big African cities including those in Nigeria are faced with the problem of rapidly deteriorating physical and living environment. The deterioration manifests itself in the form of slums, urban sprawl and squatters' settlements, increasing traffic congestion, flooding and erosion, deteriorating infrastructure and short falls in service delivery among others.

For most developing countries, the governance and management of their towns and cities are most daunting as the cities appear to be growing beyond the control of planners, beyond management capacities and beyond available resources (Agbola and Olurin 1998). Since man's quest for change will continue within his dynamic environment, this points to the fact that urbanization becomes an inevitable phenomenon particularly in developing countries. Contemporary comparative international experiences do show that the problems have to be approached with innovative ingenuity and solved through novel strategies which are consensual and adaptive to the socio-economic and cultural setting of the target population.

In the realization of this objective therefore, the paper proposes a planning strategy that addresses the problems of urban sprawl in Nigeria. The paper examines urbanization trends in Nigeria. It further discusses the characteristic features of urban sprawl in Nigerian cities and examines efforts puts in place in the past to address its attendant problems. Considering the limitations of these efforts, the paper finally suggests a feasible strategy which is adaptive to African socio-cultural milieu for the management of urban sprawl in Nigerian cities. 


\section{NIGERIA: THE CASE STUDY}

Nigeria was a former British Colony in Africa. It received her independence on $1^{\text {ST }}$ October, 1960. Nigeria operates a Federal structure of government, made of 36 States and a Federal Capital Territory. It is politically divided into 774 local government council areas. Nigeria has a land area of about $923,768 \mathrm{~km}^{2}$ and the spatial distribution of population in Nigeria is uneven, with about 64 percent of the population living in the rural areas. The entire population of Nigeria as at 2006 is put at 140.5 million (National Population Commission 2007)

Nigeria is the $13^{\text {th }}$ largest oil producer in the world with 32 billion barrels of oil reserves (DFID 2005). Available data shows that over 70 per cent of the country's annual earnings come from crude oil export proceeds; petroleum profit tax and royalty. All levels of government in Nigeria depend heavily on oil revenue that is subjected to massive shocks thereby threaten the integrity of the budget at all levels of government (Central Bank of Nigeria 2004). In spite of the earnings from oil, over 75 million people in Nigeria live in absolute poverty.

The problems of infrastructure deficiencies are particularly pronounced in the old, indigenous core areas of the Nigerian cities, and in the outer spontaneous settlements that accommodate the low-income population (Olanrewaju 2001). Besides, it has been estimated that Nigeria requires some 8 million housing units to accommodate her growing population by the year 2015. This is generally considered unachievable in the face of the on-going sporadic rate of urban sprawl in Nigerian cities that are characterized by substandard housing. Hence, there is the need to evolve a feasible strategy to address the sprawling problems of Nigerian cities.

\section{RESEARCH METHODOLOGY}

The method of investigation adopted in the research essentially relied on published and unpublished materials and sundry informal investigations (that is observations) from various stakeholders that were partakers in the sprawling development of Nigerian cities. The stakeholders are the Urban and Regional Planning Agencies that are saddled with the responsibilities of controlling physical development, land owners and property developers at peripheries of the selected cities for the study. The selected cities are Akure, Ibadan and Ado-Ekiti. These selections were based on convenience. The Nigerian census figures for the various national census exercises undertaken since 1952 to 2006 were assessed. This guides in the presentation of the urbanization trends in Nigeria. Reports of Master plans prepared for some Nigerian cities and towns were also evaluated. Assessment of land uses in the peri-urban areas of these cities and towns were equally carried out. In addition, the research collates the experiences of government and nongovernmental agencies, community institutions, and inhabitants of peri-urban zones (in which the sprawling developments are pronounced) in managing urban sprawl. The findings of this investigation are presented in this paper.

\section{URBANISATION TRENDS IN NIGERIA}

Urbanisation is a global phenomenon and is a process of spatial concentration of urban population that is premised on some basic push and pull factors called urban transformation forces, which Agbola (2006) classified into three major processes. These are (a) natural increase in the population (National growth rate or the ratio of birth to death rates); (b) rural-urban migration, and (c) city annexation into the surrounding rural areas (a real expansion). These processes explain urban population growth.

However, Deblij (1996) posited that while urban growth depends on the natural increase of the total population that is already urban; the growth of city population through the natural increase has minimal effects on the process of urbanization. Consequently, proportional increase in the population of urban dwellers is largely due to transformational forces of rural-urban migration and area expansion. Thus, resulting into the growth of settlements from villages to towns, cities and mega-cities; as well as leading to the increase in the number of settlements through the establishment of new ones.

In Nigeria for instance, by 1952 National Population Census, the population of Nigeria was put at 30.4 million, out of which 3.237 million people were living in 56 urban centers (Afolayan 1978). A city was then regarded (defined) as a settlement that harboured 5,000 people. Besides the Government Reservation Areas (GRAs) in the 3 regional government headquarters at Ibadan, Enugu, Kaduna, and Lagos the National 
headquarters; none of the remaining cities in Nigeria could boast of enjoying a re-planning project.

The classification criterion for an urban centre was increased to a threshold population figure of 20,000 during the 1963 National Population Census. As shown in Table 1, the 1963 census indicated that the population of Nigeria had increased to 55.67 million people out of whom 10.6 million people were then living in 183 cities and towns that constituted 19.1 percent of the total population (Olujimi 2000). The 1991 National Population Census gave the population of Nigeria at 88.5 million, and it shows that Nigerian urban population had risen by 36.3 percent with 359 urban centres existing in the country then (Odeyemi 2002).

By 2004, Agbola estimated the total population of Nigeria at 115 million and speculated that Nigerian urban centres must have risen to 600 (Agbola 2004). However, the speculation of Agbola (2004) notwithstanding, the fact remains that population of Nigeria has been increasing tremendously. This is confirmed by the provisional result of the 2006 National Population Census that indicated the total population of Nigeria at 140,542,032 (National Population Commission 2007). The details of the breakdown in terms of population figure for each of the urban centres and the percentage of urban to rural population are still being awaited from the National Population Commission.

In the above described scenario, it is observed that compared to the growth rate of about 3 percent for the total population, the urban population in Nigeria over the last three decades has been growing close to about 5.8 percent per

Table 1: Urban population growth trend in Nigeria 1952-2006

\begin{tabular}{lcc}
\hline Year & $\begin{array}{c}\text { Total national } \\
\text { population } \\
(\text { Million })\end{array}$ & $\begin{array}{c}\text { No. of } \\
\text { urban centres } \\
(20,000+)\end{array}$ \\
\hline 1952 & 30 million & $56 *$ \\
1963 & 55.67 million \\
1991 & 88.5 million \\
$2004 * *$ & 115 million & 183 \\
2006 & 140 million & 359 \\
Sources: Afolayan (1978), Olujimi (2000), and Agbola \\
$(2004)$.
\end{tabular}

annum. This is amongst the highest urban growth rates in the world due mainly to migration from the rural to urban areas. For instance, Lagos, a former capital of Nigeria is growing in size by more than 10 percent per year, which will make it the third largest city in the World by 2020 (DFID 2005).

One significant feature of the urbanization process in Nigeria and most of the developing countries is that, unlike America and Europe, much of the growth is taking place in the absence of significant industrial expansion. However, the explosive growth of the Nigerian urban centres has not only progressively complicated and exacerbated inter-related problems of human settlements and the environment, but has also greatly accelerated poverty, the demand for infrastructure, basic services and housing in expanding urban centres, otherwise resulting into urban sprawl.

\section{DEFINITION AND CHARACTERISTIC FEATURES OF URBAN SPRAWLIN NIGERIAN CITIES}

Microsoft Encarta (2005), gives the definition of urban sprawl as the outward spread of builtup areas caused by their expansion. The expansion of the urban area is towards its country-side that surrounds it. The urban sprawl is believed to be one of the by-products of urbanization. Cities are generally regarded all over the world as providing the engines of economic development both for the cities themselves and their surrounding rural hinterland (UN-Habitat 2004). This is the major reason why cities are regarded as depots of opportunities for the urban dwellers to exploit for their economic and social development; as well as magnetic poles that attract rural dwellers via rural-urban migration from their surrounding rural hinterland. Without any doubt, an urban centre (city) would only serve as engine of development if it (i.e.) is economically healthy, properly planned and managed in a way that would allow for efficient and functioning operations of infrastructural facilities among others. Otherwise, it can truly be drag on economic development (Ravallion 2001).

Due to uncontrolled urbanization, one major feature of Nigerian cities is urban sprawl. The urban sprawl is characterized by haphazard housing development in the urban suburbs, where majority of the structures are without 
planning permit in uncoordinated layouts. Often times, these structures are products of squatters that choose to settle at the suburbs as a result of their inability to afford residential accommodation in the city. The improper coordination of the physical development promotes high level of inaccessibility within the area. The area lacks essential social and welfare infrastructure like water, electricity, health care and educational facilities among others. The unsanitary conditions in the area poses continuous threat to healthy living of the inhabitants and it is an area regarded as area that is dangerously unsafe for living because of its associated social vices. Above all, urban sprawl presents a repulsive outlook of the city space that calls for re-planning.

Unfortunately, there is no Nigerian city that can be exonerated from the stigmatization of urban sprawl. This has prompted Farunkanmi (2003), to draw the attention of town planners to the implications of sprawling city that if the governing authorities fail to inject the essential infrastructural facilities, such neglect would pose serious and dangerous implications for human health, progress and development. From the discussion so far, urban sprawl poses a lot of challenges to town planners, city managers, governments and stakeholders. It becomes expedient to identify the causes or factors responsible for urban sprawl in Nigerian cities.

\section{FACTORS RESPONSIBLE FOR URBAN SPRAWL IN NIGERIAN CITIES}

Different factors are responsible for urban sprawl in Nigerian cities. The unprecedented increase in the population in the Nigerian cities continues to put pressure on the existing housing facility. The inability of the housing delivery to cope effectively with the housing need has succeeded in pricing out majority of the low income-earners from the housing market. Most affected groups are the immigrants from the rural hinterland that prefer to settle at the suburbs of the cities. Often times, this is responsible for the development of squatter's settlement at the periurban zones (Olujimi and Gbadamosi 2007)

Cities present unlimited socio-economic opportunities, particularly in area of landed property development. The operations of the economic forces in the supply of land for commercial development within the city centre are encouraging the acquisition of land at the suburb of the city for residential property development. This has sufficiently propelled the greed for land speculation and hoarding at the suburbs.

Unfortunately, most of the isolated parcels of land hoarded at the suburb are not subjected to conventional design into layouts that could seek planning approval. Even when such parcels of land are designed into layouts, most of them are not properly charted to allow for coordination. Hence, most of the layouts are not linked to others for accessibility purposes. Another factor that is responsible for the promotion of urban sprawl is the inability of government to effectively develop their compulsorily acquired parcels of land in some cities. This is predicated on the nonreadiness of government to pay compensations on un-exhausted resources in the acquired land to the owners. Thus, the unwillingness of the owners to release fully the acquired land to government and their continuous disposal of the land to individuals, that continues to develop the land' without reference to the planning authorities to seek planning permission.

However, the planning authorities put in place are expected to control physical development in all parts of the city (including the sprawling areas) but the ineffectiveness of the development control tool at putting such sprawl at bay is hindered by a lot of factors. These among others include lack of political will to implement development control measures, insufficient planning staff to carryout effective monitoring, and lack of equipment such as development control monitoring vehicles. In spite of the shortcomings, efforts are being made at different quarters to check the sprawling growth of Nigerian cities. These efforts are examined in the next section of the paper with a view to highlighting the limitations as to serve as guides in suggesting new strategy.

\section{OVERVIEW OF EFFORTS MADEAT CHECKING URBAN SPRAWLIN NIGERIAN CITIES}

Urbanization and its attendant problems have constituted huge challenges to the received knowledge, (both in theory and in practice) in urban planning and management. The appropriateness of conventional urban planning approach to the improvement of urban environmental conditions in the face of deteriorating urban 
Table 2: Cases of contravention by types of developers in Abuja, Nigeria 1998

\begin{tabular}{lcccccc}
\hline Agencies & Central District & Gariki & Wuse & Maitama & Asokoro & Total \\
\hline Govt Agencies & 7 & Nil & 4 & 3 & 5 & 19 \\
Private Sector & 2 & 14 & 19 & 41 & 4 & 80 \\
Diplomatic Mission & Nil & Nil & Nil & 1 & Nil & 1 \\
\hline Total & 9 & 14 & 23 & 45 & 9 & 100 \\
\hline
\end{tabular}

Source: Falade, B (2001) P 73

Note: Govt. $=$ Government

environment have often been questioned (Agbola 2006). It became imperative to search for new concepts for the emancipation of lowincome urban communities.

In this respect therefore, United Nations Development Programme (UNDP) and United Nations Centre for Human Settlement (UNCHS) have subsequently initiated strategies to evolve a participatory approach to the development and management of urban environment hinged on the principle of sustainable development (Ogu 2000). Popular among this is the Sustainable City Programme (SCP) which promotes a positive vision where all humans have adequate shelter, healthy and safe environment, basic services and freely chosen employment. It also places strong emphasis on gender equality, partnership and good urban governance. In Nigeria, the Sustainable City Project (SCP) was first applied in Ibadan, i.e. Sustainable Ibadan City Project (SICP) in 1992; and subsequently replicated in Kano and Enugu while the Sustainable Ibadan City Project had been abandoned due to nonreadiness of the major stakeholders (Oyo state government and the local government council authorities) to contribute their counterpart funding and the projects at Enugu and Kano have only started with skeletal ground works.

Ever before the introduction of Sustainable City Project in Nigeria, significant efforts had been made at redressing urban decay particularly at the core area in Nigerian cities in form of urban renewal programme but this was not extended to the urban sprawl at the peripheries of the Nigerian cities. This is because urban sprawl had not been seen as physical development problem that needs special focus except in form of preparing master plan for the existing settlement, a project that is believed to take care of the sprawling growth of the settlement in question.

Besides the fact that not many cities and towns can boast of having master plan, the few cities and towns with master plan had become obsolete without any significant efforts to get them reviewed. Disappointedly, the few cities and towns with current master plan suffer the non-political will to implement/effect the development control measures that could check urban sprawl (Olujimi and Fashuyi, 2004). For instance, the Federal Capital Territory Abuja master plan, whose implementation is expected to make Abuja the pride of Nigeria, had suffered significant bastardizations pre-1999. Table 2 shows that most physical development that contravened the provisions in the master plan are from the private sector, which has 80 out of the 100 worst cases. It is interesting that government itself is not left out, having as much as 19 cases of contraventions while the remaining one was by an embassy.

The cases of contravention in Abuja as analyzed are not unique. They are features of the planning experience in other towns and cities in Nigeria, where growth is rapid and development control cannot cope with pressures of the development. Examples of these cities are Lagos, Enugu, Kaduna, Kano, Benin, Ibadan and Akure amongst others. However, the implementation of the Abuja mater plan under the administration of the former president Olusegun Obasanjo (1999May 2007) controlled physical development in the city in spite of the political obstacles introduced by the previous administrations at bastardizing the master plan (Kalgo and Ayileka 2001; Olujimi and Ayeni 2006).

Another effort at checking urban sprawl in Nigeria is the use of the provisions of the Nigerian Land Use Act of 1978. One of the objectives for the promulgation of the Nigerian Land Use Act in 1978 was to check urban sprawl and land speculation (Federal Government of Nigeria (FGN), 1978). The law amongst others gives power to the government at the three different levels (Federal, State and Local government) to compulsorily acquire land within their areas of jurisdiction for development in the overall interest of the people. The Act however, provides for the payment of compensation for the existing 
development on the acquired land and not for undeveloped land. The implementation of the Act continues to witness hindrance because of the failure on the part of the government for not recognizing the cultural rights of the land-owners.

Even when land acquisitions are made by governments, their non-readiness to pay compensation to land-owners prompts owners of the land pronounced as acquisition to take-over and dispose such parcel of land illegally to individual developers. The developers now develop their land without any recourse to the Area Urban and Regional Planning Office yet the planning office feels unconcerned believing that they are illegal developments on government acquisitions. The non-readiness of the government to pay compensation cannot be attributed to non-availability of funds but to lack of interest at attaching priority to such projects in terms of budgetary allocation and disbursement of funds. Rather than serving as check on the development of urban sprawl, the activities of the land-owners succeed in promoting urban sprawl.

Under the State Urban Development Programme in 1985, each of the 36 State governments in Nigeria acquired and paid full compensation on the acquired parcels of land at different locations in their respective state capitals. The objectives of the programme amongst other is to improve institutional structures at the state and local levels and to strengthen urban management systems for the financing, delivery and maintenance of public services and infrastructure; and to improve the living conditions of the urban poor through the physical improvement (upgrading) of communities in greatest need and the development of serviced land for low-income groups (DHV Consulting Engineers 1985). The acute housing shortage in all the state capitals prompted the State governments in Nigeria to embark on the sites and services project as a means to improve directly on the housing delivery but to check indirectly the problem of urban sprawl. Disappointedly, most of the locations selected for the project suffered low patronage due to the far distances of the project sites to the developed parts of the cities where the projects are sited (Onibokun 1997). In spite of these efforts, cities in Nigeria are ridden with urban sprawl and this calls for people-oriented strategy at addressing the problem of urban sprawl.

\section{A SUGGESTED PLANNING STRATEGY}

The problem of urban sprawl cannot be regarded as devoid of planning solutions in spite of all the past approaches that have not curtailed the associated physical planning problems attributable to urban sprawl. This reinforces the fact that there is the need for the introduction of a dynamic strategy that would consider the peculiarities of Nigerian cities. The ineffectiveness in the use of master plan to curtail the spread of urban sprawl in Nigerian cities is not as a result of the unimproved "political will" to implement the provisions of the master plan alone but the financial requirements to prepare and implement master plan are not readily available.

The solution therefore, readily lies with the people (i.e. the developers). All that is required is to guide the people through the use of effective advocacy in their physical development activities. Therefore, State Urban and Regional Planning Board (as designated in the Nigerian Urban and Regional Planning laws) or the agency saddled with the responsibility in the state need to adopt the approach of "planning with the people" and not necessary "planning for the people" with a view to collaborate the people's efforts with that of the government in their physical development bids. This might be qualified and described as Public-Private Partnership (PPP) in physical development planning of Nigerian cities with a focus at checking urban sprawl.

The use of advocacy in the enlightenment of the communities and land-owners residing at the city suburbs is to see their relevance in accepting sound physical planning principles. The Chief Executive Officers of the Local Planning Authorities at their various local government areas of their jurisdiction should identify parcels of land at different locations in the suburbs of cities and towns for development under this approach. Rather than the owners of such parcels of land developing them as illegal structures and the Executive Officers of the Local Planning Authorities scaring them with demolition notices that are never enforced; arrangement of meetings with the land-owners at educating them on the need for the development of their land in harmony with planning regulations should be embarked upon.

Even when the land-owners do not have the money either to pay for the cost of carrying out the perimeter surveying or the cost of laying out (i.e. sub-dividing) the parcels of land into plots; 
the Chief Executive Officers of the Local Planning Authorities should facilitate arrangement between the land-owners and relevant individual professional firms that would render the required services in the preparation of the layout plans. The arrangement therefore, is to ensure that these services are rendered on the understanding that agreed number of building plots would be released to the professionals in returns for their services.

The advantages of this approach are in three folds. First, the inability of most communities and families to pay the professional fees for both surveying and laying out of their parcels of land due to high poverty level would be completely avoided. Second, the approach would promote physical development of the city-suburbs in line with the provisions of planning regulations as well as enhance the financial value of their land. Third, it would encourage many communities and families to come out openly to participate in the physical development of their land rather than outright acquisition of their land by government on which compensations are not paid and for which such land are not readily developed by the government. Besides all these, the approach gives land-owners and communities' sense of belonging and it energizes communities to embrace physical planning. It will equally allow for the effective use of development control in the laid out areas and ensure that the involvement of the communities in the provision of infrastructure gains wider acceptance.

However, it becomes expedient to sound a note of warning to the Chief Executive Officers of the Local Planning Authorities that their involvement in the facilitation of this arrangement should not be on the premise of exploiting the communities or the land-owners of their financial benefits but essentially to ensure that the city suburbs are well-planned. Nonetheless, the approach cannot be completely insulated from abuse by greedy Chief Executive Officers and other Urban and Regional Planning Officers working in the Local Planning Authorities but a close monitoring of the planning activities by the State Urban and Regional Planning Board would eliminate the possible abuse. In case of any abuse, erring officers found wanting should be prosecuted under relevant laws of the land especially under the anti-corruption laws.

\section{CONCLUSION}

One basic factor that is essential to success- ful implementation of planning project is to embrace sound planning practice that is based on evolving principles. It is time for city dwellers particularly in Nigeria and other developing countries to note that government resources are limited and its areas of attention are unlimited. This has made the need for collaboration between government and the public in curtailing urban sprawl. Therefore, the strategy of planning with the communities in a bid to check urban sprawl as suggested would go in no small measure at enlisting the support of the developers

\section{REFERENCES}

Afolayan AA 1978. Population. In: Oguntoyinbo JS Areola OO and M Filani (Eds.). A Geography of Nigerian Development. Ibadan: Heinemann Educational Books Nigeria Limited, pp. 113-123.

Agbola T 2004. The Nigerian Urban Development Policy: If the Past be Prologue. Paper Presented at the $34^{\text {th }}$ Annual Conference of the Nigeria Institute of Town Planners at Abeokuta, October 22 to 24, 2004.

Agbola T 2006. Sustainable Urbanisation and the New Urban Planning: Dilemma of New Opportunities and the Challenges for Nigeria Technocratic Planners. A paper Presented at the $2^{\text {nd }}$ Postgraduate Diploma Regular Forum lecture series. in the Dept. of Urban and Regional Planning, Rufus Giwa Polytechnic, Owo, $3^{\text {rd }}$ June, 2006.

Agbola T, Olurin T 1998. Sustainable Cities Programme (SCP): The Origin, Lessons of Experience and a Case Study of the Sustainable Ibadan Project (SIP). In Adeniji K and VI Ogu (Eds.). Sustainable Physical Development in Nigeria, Ibadan: Nigerian Institute for Social and Economic Research (NISER) Publication, pp. 271-299.

Central Bank of Nigeria 2004. Report on the Millennium Development Goals, Occasional Report. Abuja: Central Bank Office.

DeBlij HJ 1996. Human Geography: Culture Society and Space. New York: John Wiley and Sons.

Department of International Development (DFID) 2005. Nigeria by Numbers. Development Magazine, 32: 8 -9 .

DHV Consulting Engineers 1985. Report on Ondo State Urban Development Project. Preparation Study Final Report, Amersfoort.

Donk VM 2006. Positive Urban Futures in Sub-Saharan African: HIV/AIDS and the Need for A Broader Conceptualisation (ABC). Environment and Urbanisation, 18(1): 155-177.

Falade B 2001. Location of Recreational Facilities, Parks and Gardens Development in the Context of the Abuja Master Plan Review. In: Kalgo MSU and O Ayileka (Eds.).The Review of Abuja Master Plan. Ibadan: Fountain Publications Ltd., pp. 57-84.

Farunkanmi O 2003. Controlling Urban Sprawl through Effective Urban Governance. A Paper Presented at the Monthly Meeting of the Ondo State Chapter of 
Nigerian Institute of Town Planners, Akure, on March 27, 2003

Federal Government of Nigeria (FGN) 1978. Nigerian Land Use Act. Federal Ministry of Information. Lagos.

Kalgo MSU, Ayileka O (Eds.). 2001. The Review of Abuja Master Plan. Proceeding of the International Workshop for the Review of Abuja Master Plan, held November $29^{\mathrm{TH}}$ to December $2^{\mathrm{ND}} 2001$.

Microsoft Encarta 2005. Urban Sprawl. Encarta Dictionary. (Retrieved June 6, 2005).

National Population Commission (NPC) 2007. Nigeria 2006 Census Provisional Results. National Population Commission, Abuja.

Odeyemi Y 2002. Gender Inequality and Urbanisation in Nigeria. In: D Amole, MO Fadare (Eds.): Proceeding of National Conference Organised by the Faculty of Environmental Design and Management, Obafemi Awolowo University, Ile-Ife, pp. 97-103.

Ogu VI 2001. Stakeholders Partnership Approach to Infrastructure Provision and Management in Developing World Cities: Lessons from the Sustainable Ibadan Project. Habitat International, 20: $517-53$.

Olanrewaju DO 2001. Urban Infrastructure: A Critique of Urban Renewal Process in Ijora Badia. Habitat International, Lagos, 25: $373-384$.

Olujimi JAB 2000. Local Government and Urban Management in Africa: The Nigerian Perspective. African Journal of Social and Policy Studies, 1(1): $162-170$.

Olujimi JAB, Fashuyi OS 2004. Anatomy of 'Illegal Structures' in Akure Metropolis, Ondo State, Nigeria.
Journal of the Nigerian Institute of Town Planners XVII: $79-96$.

Olujimi JA, Ayeni DA 2006. Green City Project Experience: Lessons for Nigeria. In: Okewole IA Daramola SA, Ajayi, CA, Ogunba OA, KT Odusanmi (Eds.): The Built Environment: Innovation Policy and Sustainable Development. Proceeding of International Conference Organised by Covenant University, Sango-Otta, pp. 246-252.

Olujimi J, Gbadamosi K 2007. Urbanisation of Peri-Urban Settlements: A Case Study of Aba-Oyo in Akure, Nigeria. The Social Sciences, 2(1): 60-69.

Olurin TA 2003. Gender Participation and the Environmental Planning and Management (EPM) Process: A Case Study of Water Supply in Bodija Market, Ibadan. Journal of the Nigerian Institute of Town Planners, XV1: $1-18$.

Onibokun AO 1997. Nigerian Cities in the $21^{\text {st }}$ Century. A paper delivered at the 1997 World Habitat Day Celebration organsed by the Federal Ministry of Works and Housing, Abuja on $6^{\text {th }}$ October, 1997.

Ravallion M 2001. On the Urbanisation of Poverty. Policy Research Working Paper No. 2586, Washington, D.C: The World Bank.

Tibaijuka AK 2006. A Message from the Executive Director. Habitat Debate, 12(2): 12

United Nation Centre for Human Settlements (UNHabitat) 2004. Cities - Engines of Rural Development, Habitat Debate, 10(3): 1-23.

United Nations Centre for Human Settlements (UNHabitat) 2006. Cities-Magnets of Hope. 2006 World Habitat Day Celebration Release, Nairobi. 